"Mircea cel Batran" Naval Academy Scientific Bulletin, Volume XIX - 2016 - Issue 1

Published by "Mircea cel Batran" Naval Academy Press, Constanta, Romania /I The journal is indexed in:

PROQUEST / DOAJ / DRJI / JOURNAL INDEX / I2OR / SCIENCE LIBRARY INDEX / Google Scholar / Crossref /

Academic Keys / ROAD Open Access / OAJI / Academic Resources / Scientific Indexing Services / SCIPIO

\title{
DATA ACQUISITION AND ANALYSIS OF LOW FREQUENCY ELECTROMAGNETIC FIELD
}

\author{
Petrica POPOV ${ }^{1}$ \\ Paul BURLACU² \\ Vasile DOBREF ${ }^{3}$ \\ Florentiu DELIU 4 \\ ${ }^{1}$ Lecturer PhD Naval Academy "Mircea cel Batran", Constanța, petrica.popov@anmb.ro \\ 2Lecturer PhD eng.Naval Academy "Mircea cel Batran", Constanța, paul.burlacu@anmb.ro \\ ${ }^{3}$ Professor PhD eng. Naval Academy “Mircea cel Batran”, Constanța, vasile.dobref@anmb.ro \\ ${ }^{4}$ Lecturer PhD eng.Naval Academy “Mircea cel Batran”, Constanța, florentiu.deliu@anmb.ro
}

\begin{abstract}
In recent years more and more studies have shown that, the low frequency field strength (particularly magnetic, $50 / 60 \mathrm{~Hz}$ ) are a major risk factor; according to some specialists - even more important as the radiation field. As a result, the personnel serving equipment and facilities such as: electric generators, synchronous, the motors, the inverters or power transformers is subjected continually to intense fields, in their vicinity, with possible harmful effects in the long term by affecting metabolism cell, respectively, the biological mechanisms.

Therefore, finding new methods and tools for measurement and analysis of low frequency electromagnetic fields may lead to improved standards for exposure limits of the human body.
\end{abstract}

Keywords: power density; exposure limits; spectrum analyzer

\section{Introduction}

For assessing the human exposure to electromagnetic field, measurements will especially aimed strength(power, amplitude) field as the most relevant parameter. Since the exposure comes from many sources, environmental and occupational, its power will be a resultant of powers fields that propagate in several directions. In this respect, can be performed two types of measurements with specific devices: measuring broadband (with devices that detect signals in a wide range of frequencies) and measuring the selected frequency.

It will also be taken into account the two main components of the electromagnetic field:

$>$ reactive component that relates to the energy stored in the vicinity of the source region and is responsible for effects on humans. This region is located around the source, up to a distance of approx. $0.2 \mathrm{~m}-2 \mathrm{~m}$ (near field region). The measurements in the near field region are difficult, because even the introduction of probe for measuring may change substantially the field value;

$>$ radiative component is found at greater distances from one wavelength (far-field region), where electromagnetic wave can be described as a plane wave, the ratio of the electric field and magnetic field strength is constant. This feature makes sufficient measurement of one component of the field.
Between the two regions characterized by two components there is a transition zone, dominated by radiative component. Because the wavelength is inversely proportional to the frequency, these regions vary considerably, from $1 \mathrm{~mm}$ to $100 \mathrm{~km}$ in the radiofrequency band. For example, higher frequency of $300 \mathrm{MHz}(<1 \mathrm{~m})$ population exposure occurs in the far field region, unless that person is coming from a distance of one meter $(1 \mathrm{~m})$ source.

Generally, the effects produced on humans, for near and far field, are:

- Non-thermal effects can occur due to many interactions between different components of the electric field and biological tissue

- Thermal effects can occur due to electrical conductivity of most biological tissues. To characterize the thermal effects are relevant following parameters:

- The conductivity of biological tissue:

$$
\sigma=2 \pi f \varepsilon "[S / m]
$$

- Absorbed power per unit volume:

$$
P_{a}=\frac{1}{2} \sigma|\bar{E}|^{2}\left[W / m^{2}\right]
$$

- SAR (Specific Absorption Rate) power absorbed per unit mass of tissue:

$$
S A R=\frac{P_{n}}{\rho}=\frac{\sigma}{2 \rho}|\bar{E}|^{2}[W / \mathrm{kg}]
$$




\begin{abstract}
"Mircea cel Batran" Naval Academy Scientific Bulletin, Volume XIX - 2016 - Issue 1
Published by "Mircea cel Batran" Naval Academy Press, Constanta, Romania /I The journal is indexed in: PROQUEST / DOAJ / DRJI / JOURNAL INDEX / I2OR / SCIENCE LIBRARY INDEX / Google Scholar / Crossref /

Academic Keys / ROAD Open Access / OAJI / Academic Resources / Scientific Indexing Services / SCIPIO
\end{abstract}

Specific to low frequency radiation (electromagnetic field) it is used the term of nonionization radiation which is referred to a radiation that has enough energy to move atoms in a molecule around or cause them to vibrate, but not enough to remove electrons. Examples of this kind of radiation are radio frequency, visible light, and microwaves. Ionization radiation is referred to a radiation range that has enough energy to remove tightly bound electrons from atoms, thus creating ions. Examples of this kind of radiation are X- rays and Gamma rays [1].

Electromagnetic waves cover a wide range of frequencies and wavelengths, which is called the electromagnetic spectrum and comprises ionizing, optical and non-ionizing radiations. The nonionizing radiation is further subdivided into static fields $(0 \mathrm{~Hz})$, extremely low frequency fields (ELF), intermediate frequency fields (IF), and radio frequency fields and microwaves (RF).

Scientists of the International Electromagnetic Fields Alliance (IEMFA), recommend reduced exposure limits for electromagnetic radiation from power lines and telecommunications technologies [2]. They recommend that global governments should adopt lower exposure guide-lines to protect current public health and that of future generations. The new recommended value is 0.1 $\mu \mathrm{T}$ which is approximately $1000-10,000$ times lower than the cur-rent ICNIRP/IEEE standards $[2,3]$. They conclude that the ICNIRP/IEEE public safety limits are inadequate and obsolete with respect to the prolonged, low intensity exposures that are common today.

\section{Measurements of low frequency electromagnetic field with Spectrum Analyzer NF-5030.}

To perform a correct and relevant measurement of electromagnetic field intensity must be taken into account:

- Compatibility of the measuring apparatus with monitored sources bandwidth;

- Measuring in three orthogonal directions at each point;

- Taking into account the fact that measurements are altered by the probe in the near field region;

- Performing measurements at several points of the location, an ambient measurement and more measurements in the proximity of sources.

Examples for possible analysis and measurements within frequency range $(1 \mathrm{~Hz}$ $30 \mathrm{MHz}$ ): traction power; power lines and cables; EMC compliance tests: EN55011, EN55022, EN55014, EN61000-6-3, 61800-3 C1, ICNIRP, VDE0848; transformers; power supplies and harmonics; TFT and LCD monitors and TVs; solar panels; magnetic resonance tomograph; $135 \mathrm{kHz}$ RFID; DSL, ADSL, VDSL

\section{Spectran NF - 5030 specification:}

- Frequency range: $1 \mathrm{~Hz}$ to $1 \mathrm{MHz}$ (extended to $30 \mathrm{MHz}$ )

- Typ. level range E-Field: $0,1 \mathrm{~V} / \mathrm{m}$ to $20 \mathrm{kV} / \mathrm{m}$

- $\quad$ Typ. level range H-Field: 0,1nT to $2 \mathrm{mT}$

- Typ. level range DDC H-Field: 1 pTto $2 \mathrm{mT}$

- Typ. level range DDC Analog in: 200nVto 200mV /-150dBm (Hz)

- Typ. accuracy: 3\%

- $\quad$ Superfast FFT spectrum analysis

- High-performance DSP (Digital Signal Processor)

- 3D magnetic field measurement

- Frequency and signal strength display

- High-resolution multi-function display

- $\quad$ Simultaneous M-Display X, Y, Z axes

- True RMS signal strength measurement

- $\quad$ Average (AVG) measurement

- Internal data logger

- Internet Flash Software-Updates

- USB 2.0 Interface

Low frequency field analyzer has the following main functions [4]:

\section{a) Real analysis.}

In a certain frequency range, the individuals signals and their respective strengths are being broken down, for example into a "bargraph" display.

The height of the individual bars represents the corresponding signal strength. For the 3 strongest signal sources, the spectrum analyzer can automatically displays the frequency and signal level, thanks to its "Auto Marker" feature. In the EMF (LF) spectrum shown in fig. 1, a frequency range of approx. $20 \mathrm{~Hz}$ to $60 \mathrm{~Hz}$ from left to right is being analysed. During analysis, the Auto Marker feature has determined - fully automatic - three main signal sources.

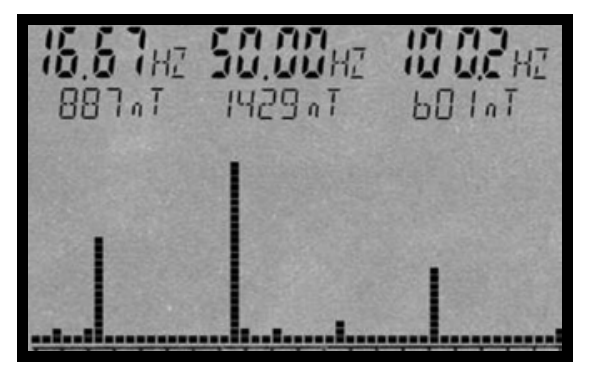

Fig. 1 LF spectrum display and automatic multimarker display on the digital screen of SPECTRAN 
"Mircea cel Batran" Naval Academy Scientific Bulletin, Volume XIX - 2016 - Issue 1

Published by "Mircea cel Batran" Naval Academy Press, Constanta, Romania // The journal is indexed in: PROQUEST / DOAJ / DRJI / JOURNAL INDEX / I2OR / SCIENCE LIBRARY INDEX / Google Scholar / Crossref / Academic Keys / ROAD Open Access / OAJI / Academic Resources / Scientific Indexing Services / SCIPIO

\section{b) Long-term measurement (data} logging feature).The spectrum analyzer measurement devices with data logger allow longterm recordings of measurement results over a freely adjustable period of time. This is particularly indispensable for serious evaluation of exposure by appliances and machinery which have a changing power consumption or radiation strength over time. Depending on the time of day, considerable variation of exposure can occur.
With long-term data logging using spectrum analyzer, the daily variation of exposure can be recorded and analysed. Thus, the actual total exposure can be evaluated precisely. Magnetic field data are presented in figure 2 and for electric field in figure 3 , in real time (a) or recorded (b).

With this functionality, it can even be discovered sporadic EMC problems which would otherwise be very hard to detect.

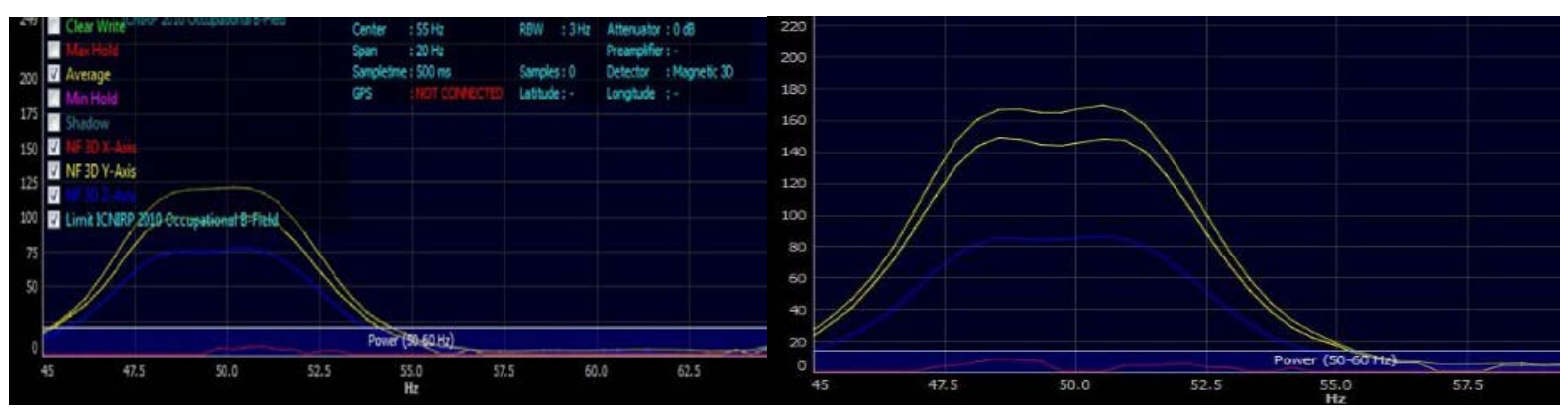

a.

$b$.

Fig. 2 Magnetic field data

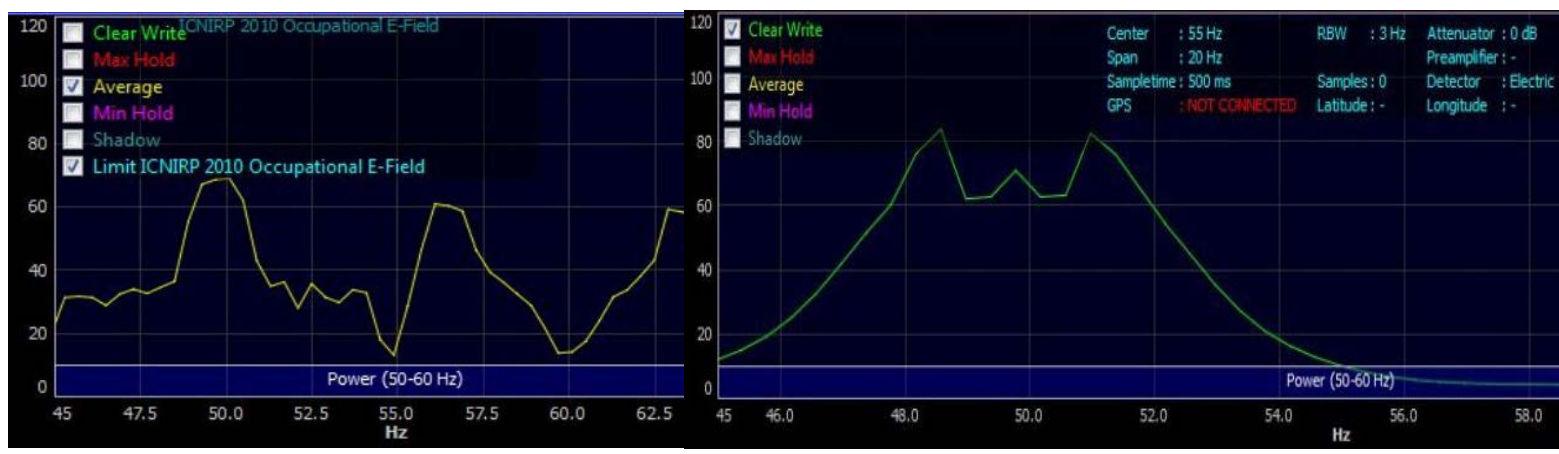

a.

$b$.

Fig. 3 Electric field data

\section{c) Exposure limits}

The indispensable, highly complex calculation of frequency-dependant exposure limits can only be performed conforming to standards by a spectrum analyser with high-performance software. They can calculate even several authoritative exposure limits, precautionary limits and recommendations (simply selectable via a button) and display these as a practical bargraph display (including convergence display in percent!), while the measurement is running.

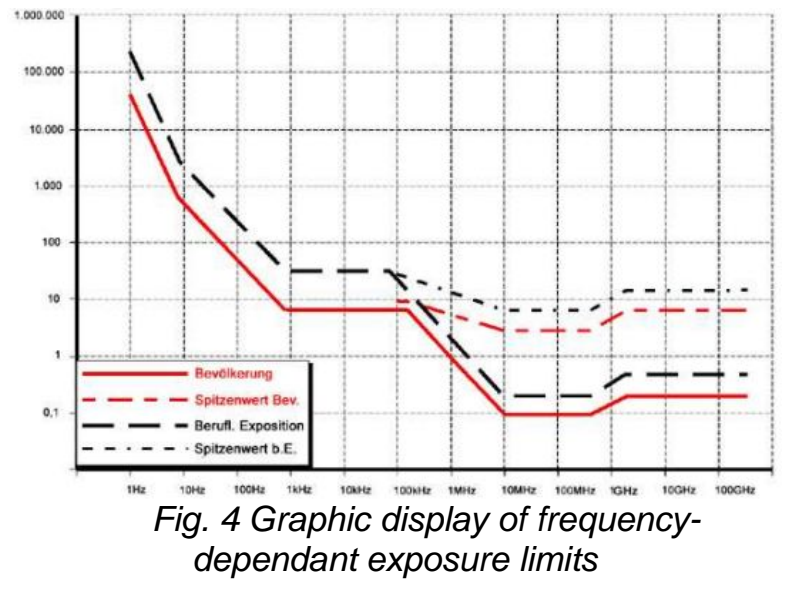

The ICNIRP exposure limit has been chosen among the various available exposure limits in figure 4 . The spectrum analizer now automatically 
"Mircea cel Batran" Naval Academy Scientific Bulletin, Volume XIX - 2016 - Issue 1

Published by "Mircea cel Batran" Naval Academy Press, Constanta, Romania /I The journal is indexed in:

PROQUEST / DOAJ / DRJI / JOURNAL INDEX / I2OR / SCIENCE LIBRARY INDEX / Google Scholar / Crossref /

Academic Keys / ROAD Open Access / OAJI / Academic Resources / Scientific Indexing Services / SCIPIO

calculates convergence or excess of this limit. For achieving this, often thousands of complex calculations have to be performed per second, and a steady scan of the entire frequency range needs to be performed. In our test case, the graphic display shows an approximation towards the ICNIRP limit by $6,06 \%$. If you use a NF-5030 you can even cover the total ICNIRP-banwidth (depending on frequency). Hence, even the novice can perform exposure limit calculations according to standards without having to use complex tables and calculators.

\section{CONCLUSION}

The harmful effects of low frequency electromagnetic field on the human body have been theoretically set and some of these have been confirmed by laboratory studies. Generally, they are produced as a result of interaction of currents induced by external electromagnetic field with human tissues. Whereas in such cases the studies on humans are very difficult to achieve because the results from long and very long exposure can delay the results with decades. So, we must be very cautious when tagging a theoretical study as inconclusive because the study cannot be fully confirmed only after a laboratory study. Also, we must be circumspect including in terms of intensity ranges allowed by the ICNIRP, which are the result of approximate multi-criteria evaluation, based on the same study more or less finalized. As a result we will need to act to reduce such risks in the absence of complete information.

\section{BIBLIOGRAPHY}

[1] ****US Environmental Protection Agency, "Ionizing \& Non-Ionizing Radiation," 9 July 2011

[2] ${ }^{* \star * *}$ The International Electromagnetic Fields Alliance (IEMFA), "Seletun Statement," 2011

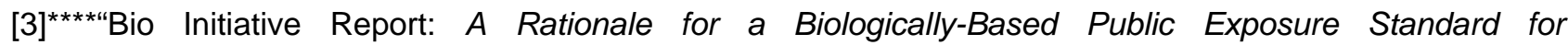
Electromagnetic Fields (ELF and RF)," 2007

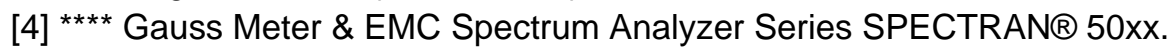

